Article

\title{
Kinetic and Mechanistic Study on Catalytic Decomposition of Hydrogen Peroxide on Carbon-Nanodots/Graphitic Carbon Nitride Composite
}

\author{
Zhongda Liu, Qiumiao Shen, Chunsun Zhou, Lijuan Fang, Miao Yang * and Tao Xia * \\ School of Chemistry, Chemical Engineering and Life Sciences, Wuhan University of Technology, \\ Wuhan 430070, China; liuzhongda@whut.edu.cn (Z.L.); shen_qiumiao@163.com (Q.S.); \\ zhouchunsun@whut.edu.cn (C.Z.); fanglijuan@whut.edu.cn (L.F.) \\ * Correspondence: yangmiao@whut.edu.cn (M.Y.); hsiatao@hotmail.com (T.X.); \\ Tel.: +188-7225-6465 (M.Y.); +134-0714-2371 (T.X.)
}

Received: 12 September 2018; Accepted: 8 October 2018; Published: 11 October 2018

check for updates

\begin{abstract}
The metal-free CDots/g- $\mathrm{C}_{3} \mathrm{~N}_{4}$ composite, normally used as the photocatalyst in $\mathrm{H}_{2}$ generation and organic degradation, can also be applied as an environmental catalyst by in-situ production of strong oxidant hydroxyl radical (HO·) via catalytic decomposition of hydrogen peroxide $\left(\mathrm{H}_{2} \mathrm{O}_{2}\right)$ without light irradiation. In this work, CDots $/ g-\mathrm{C}_{3} \mathrm{~N}_{4}$ composite was synthesized via an electrochemical method preparing CDots followed by the thermal polymerization of urea. Transmission electron microscopy (TEM), X-Ray diffraction (XRD), Fourier Transform Infrared (FTIR), $\mathrm{N}_{2}$ adsorption/desorption isotherm and pore width distribution were carried out for characterization. The intrinsic catalytic performance, including kinetics and thermodynamic, was studied in terms of catalytic decomposition of $\mathrm{H}_{2} \mathrm{O}_{2}$ without light irradiation. The second-order rate constant of the reaction was calculated to be $(1.42 \pm 0.07) \times 10^{-9} \mathrm{~m} \cdot \mathrm{s}^{-1}$ and the activation energy was calculated to be $(29.05 \pm 0.80) \mathrm{kJ} \cdot \mathrm{mol}^{-1}$. Tris(hydroxymethyl) aminomethane (Tris) was selected to probe the produced $\mathrm{HO}$ - during the decomposing of $\mathrm{H}_{2} \mathrm{O}_{2}$ as well as to buffer the $\mathrm{pH}$ of the solution. The composite was shown to be base-catalyzed and the optimal performance was achieved at $\mathrm{pH}$ 8.0. A detailed mechanism involving the adsorb-catalyze double reaction site was proposed. Overall, CDots $/ g-\mathrm{C}_{3} \mathrm{~N}_{4}$ composite can be further applied in advanced oxidation technology in the presence of $\mathrm{H}_{2} \mathrm{O}_{2}$ and the instinct dynamics and the mechanism can be referred to further applications in related fields.
\end{abstract}

Keywords: CDots /g- $\mathrm{C}_{3} \mathrm{~N}_{4} ; \mathrm{H}_{2} \mathrm{O}_{2}$; hydroxyl radical; Tris; advanced oxidation technology

\section{Introduction}

Advanced oxidation technology (AOT) is one of the most effective and economical approaches dealing with non-biodegradable organic pollutants (NBDOPs) in water, such as dyestuffs, pesticides, pharmaceutical and personal care products (PPCPs), synthetic chemicals and leachate of landfills [1-5]. In typical AOTs, different strategies like chemical, photochemical, sonochemical and electrochemical pathways, are employed to produce intermediate active oxidant radicals [1,6-8]. With an oxidation potential of $2.7 \mathrm{eV}$ and nanosecond-level life time, hydroxyl radical (HO-) is one of the most typical radicals, which can decompose NBDOPs non-selectively, forming $\mathrm{CO}_{2}, \mathrm{H}_{2} \mathrm{O}$, inorganic ions or other biodegradable molecules [9-11]. It is worthy to note that the degradation of NBDOPs and the generation of $\mathrm{HO}$ take place simultaneously [12]. Thus, the core process of various AOTs is to improve the yield of $\mathrm{HO}$, which mainly leads to the decomposition of NBDOPs. 
The concentration of instantaneous $\mathrm{HO}$. can be hardly determined directly but can be determined indirectly by probes like Rhodamine B [13], terephthalic acid [14], dimethyl sulfoxide [15], phenylalanine [16] and Tris(hydroxymethyl)aminomethane (Tris) [17]. Among the various probes, Tris can be applied in both homogeneous and heterogeneous systems as $\mathrm{HO}$. scavenger and $\mathrm{pH}$ buffer at the same time [18]. Hydroxyl radical captures hydrogen atom from Tris, producing formaldehyde $\left(\mathrm{CH}_{2} \mathrm{O}\right)$ and other compounds. Since the produced $\mathrm{CH}_{2} \mathrm{O}$ can be quantified by the modified Hantzsch method [19], the concentration of HO- can be indirectly quantified. The detailed mechanism of the reaction between $\mathrm{HO}$. and Tris was reported, involving the effects of $\mathrm{O}_{2}$ and $\mathrm{pH}$ [17].

$\mathrm{H}_{2} \mathrm{O}_{2}$ is one of the most common sources of $\mathrm{HO}$. in the presence of metal salt solution, carbon-based species, metal or metal oxide via Fenton/Fenton-like reaction, electron-transfer mechanism or catalytic decomposition on the solid-liquid interface [18,20-24]. The well-known Fenton/Fenton-like reaction may occur in both homogeneous and heterogeneous system according to many works [18,20-23]. Similar to the Fenton reaction, $\mathrm{HO}$. and $\mathrm{HO}_{2} \cdot$ can be formed on the surface of carbon-based catalysts via the electron-transfer mechanism due to the donor-acceptor properties of the carbon surface. The redox cycle is necessary to keep the production of $\mathrm{HO}$. and $\mathrm{HO}_{2}$. species [24]. The catalytic decomposition of $\mathrm{H}_{2} \mathrm{O}_{2}$ on the surface of metal or metal oxides has also been studied to some extent in recent years, including $\mathrm{Fe}, \mathrm{W}, \mathrm{Cu}, \mathrm{UO}_{2}, \mathrm{ZrO}_{2}, \mathrm{CuO}, \mathrm{CuO}_{2}$ and so on [18,22,25-27]. It is known that $\mathrm{HO}$. and $\mathrm{HO}_{2}$. will be formed as intermediates during the decomposition of $\mathrm{H}_{2} \mathrm{O}_{2}$ while the disproportion reaction of $\mathrm{HO}_{2}$. ends up with $\mathrm{H}_{2} \mathrm{O}_{2}$ and $\mathrm{O}_{2}$. The disproportionation may also occur in the Fenton/Fenton-like reaction and the reaction between $\mathrm{H}_{2} \mathrm{O}_{2}$ and carbon-based catalyst. From previous work, it is known that the reaction between scavenger and $\mathrm{HO}$ - will affect the production of $\mathrm{O}_{2}$ [28].

Despite its high efficiency and effectiveness, the application of classic Fenton reaction faces the disadvantages of strict $\mathrm{pH}$ restrictions, iron precipitation and the cost for catalyst recycling [29-31]. The formation rate of $\mathrm{HO}$. is strongly dependent on the $\mathrm{pH}$ value while the oxidation potential of $\mathrm{HO}$ - declines as the $\mathrm{pH}$ increases [31,32]. Furthermore, the generation of HO- is directly limited by the formation of iron sludge in alkaline condition [30]. Since iron precipitation remains the bottleneck of classic iron-based Fenton reaction, non-ferrous heterogeneous catalysts with multiple oxidation states and redox stability $(\mathrm{Ce}, \mathrm{Cu}, \mathrm{Mn}$ and $\mathrm{Ru})[11]$ and transition metal substituted iron oxide $(\mathrm{Cr}$, $\mathrm{Co}$ and Ti) [32], have been developed for the replacement. Nevertheless, the abovementioned metal materials still face the drawbacks of high cost, high toxicity and/or environmental unfriendliness. Hence, a number of metal-free catalysts have been developed for the generation and/or decomposition of $\mathrm{H}_{2} \mathrm{O}_{2}$ regarding to their high earth abundance, good biocompatibility and environment-friendly properties, including graphene [6], carbon nanotubes [33], activated carbon fibers [34], graphitic carbon nitride $\left(\mathrm{g}-\mathrm{C}_{3} \mathrm{~N}_{4}\right)$ [35-38] and carbon nanodots (CDots) [39].

As a metal-free polymer semiconductor material with suitable band gap and band position, g- $\mathrm{C}_{3} \mathrm{~N}_{4}$ has embodied its research value in the field of $\mathrm{H}_{2}$ production, $\mathrm{CO}_{2}$ reduction, selective oxidation of alcohols and pollutant degradation [40-43]. The combination of CDots and g- $\mathrm{C}_{3} \mathrm{~N}_{4}$ was firstly introduced in 2015 by J. Liu and her co-workers for water splitting, solving the chock point that g- $\mathrm{C}_{3} \mathrm{~N}_{4}$ is poisoned by in-situ generated $\mathrm{H}_{2} \mathrm{O}_{2}$ in hydrogen evolution [44]. $\mathrm{H}_{2} \mathrm{O}$ can be catalytically split into $\mathrm{H}_{2} \mathrm{O}_{2}$ and $\mathrm{H}_{2}$ by g- $\mathrm{C}_{3} \mathrm{~N}_{4}$ in the presence of photo irradiation. However, with the two-dimensional structure and large accessible area on the surface of $\mathrm{g}-\mathrm{C}_{3} \mathrm{~N}_{4}$, the in-situ generated hydrogen peroxides are strongly bonded and difficult to remove, which leads to the poisoning of catalyst, thereby limiting the yield of $\mathrm{H}_{2}$ [45-47]. CDots was introduced to solve this problem by decomposing the bonded $\mathrm{H}_{2} \mathrm{O}_{2}$ on the surface of $\mathrm{g}-\mathrm{C}_{3} \mathrm{~N}_{4}$ into $\mathrm{H}_{2} \mathrm{O}$ and $\mathrm{O}_{2}$, thereby remitting the poisoning of $\mathrm{g}-\mathrm{C}_{3} \mathrm{~N}_{4}$. It is known that intermediate $\mathrm{HO}$. will be formed via electron-transfer on the surface of carbon-based catalyst [24]. Inspired from these, it can be hypothesized that the CDots $/ \mathrm{g}-\mathrm{C}_{3} \mathrm{~N}_{4}$ composite can be used as a catalyst providing promising yield of $\mathrm{HO}$. via decomposing adsorbed $\mathrm{H}_{2} \mathrm{O}_{2}$ on the surface of $\mathrm{g}-\mathrm{C}_{3} \mathrm{~N}_{4}$ by embedded CDots. To the best of our knowledge, the kinetics and mechanism of catalytic decomposition of $\mathrm{H}_{2} \mathrm{O}_{2}$ on CDots/g- $\mathrm{C}_{3} \mathrm{~N}_{4}$ composite has been rarely studied. 
In this work, CDots/g- $\mathrm{C}_{3} \mathrm{~N}_{4}$ composite was synthesized via an electrochemical method followed by a thermal polymerization process. The obtained composites were characterized by TEM, FTIR, Brunauer-Emmett-Teller (B.E.T) and XRD. The catalytic performance of CDots/g- $\mathrm{C}_{3} \mathrm{~N}_{4}$ composite for $\mathrm{H}_{2} \mathrm{O}_{2}$ decomposition was also investigated. The second-order reaction rate constant of $\mathrm{H}_{2} \mathrm{O}_{2}$ decomposition and reaction activation energy were obtained by varying the dosage of composite and temperature. Furthermore, a detailed mechanism involving the adsorb-catalyze double reaction sites was proposed.

\section{Results and Discussion}

\subsection{Morphology of the Catalyst}

The obtained CDots/g- $\mathrm{C}_{3} \mathrm{~N}_{4}$ composite was prepared via an electrochemical method followed by a thermal polymerization process. To confirm the modification of CDots on g- $\mathrm{C}_{3} \mathrm{~N}_{4}$, FTIR spectra and XRD patterns of pure g- $\mathrm{C}_{3} \mathrm{~N}_{4}$ and CDots/g- $\mathrm{C}_{3} \mathrm{~N}_{4}$ composite were obtained and exhibited in Figure 1A,B. The influence of CDots modification on the specific surface area was investigated by the B.E.T. method with isothermal adsorption and desorption of high purity nitrogen. The $\mathrm{N}_{2}$ adsorption-desorption isotherms and pore size distributions of g- $\mathrm{C}_{3} \mathrm{~N}_{4}$ and CDots/g- $\mathrm{C}_{3} \mathrm{~N}_{4}$ composite are shown in Figure 1C. The TEM images of CDots/g- $C_{3} N_{4}$ are shown in Figure 1D,E.
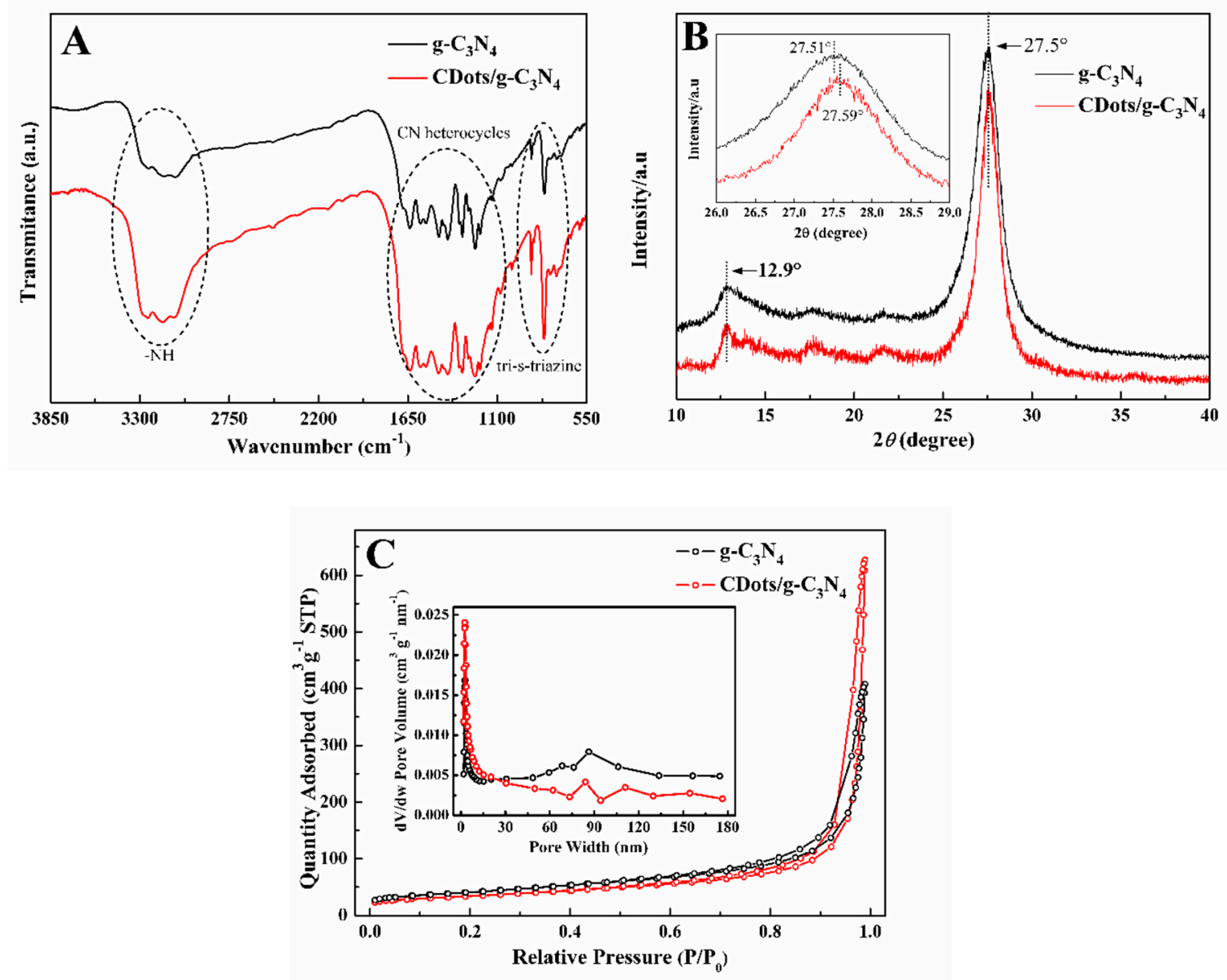

Figure 1. Cont. 


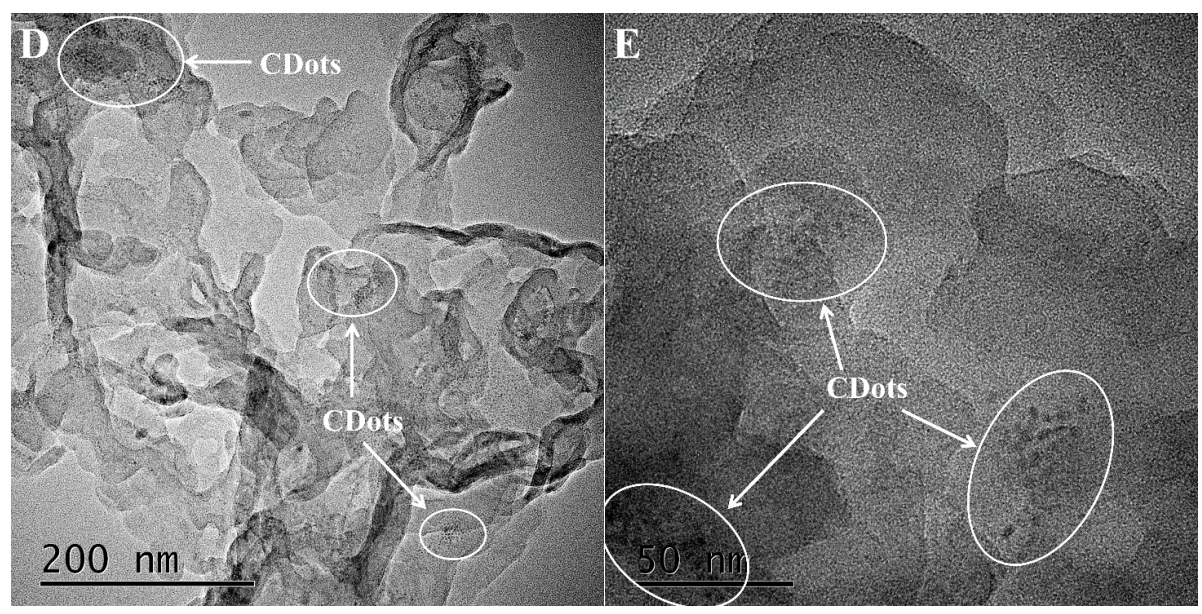

Figure 1. (A) Fourier Transform Infrared (FTIR) spectra; (B) X-Ray diffraction (XRD) patterns; (C) $\mathrm{N}_{2}$ adsorption/desorption isotherm and pore width distribution of pure $\mathrm{g}-\mathrm{C}_{3} \mathrm{~N}_{4}$ and CDots/g- $\mathrm{C}_{3} \mathrm{~N}_{4}$ composite; (D,E) Transmission electron microscopy (TEM) images of CDots $/ g-\mathrm{C}_{3} \mathrm{~N}_{4}$ composite.

As can be seen in Figure 1A, the sharp peak for g- $\mathrm{C}_{3} \mathrm{~N}_{4}$ at $810 \mathrm{~cm}^{-1}$ is attributed to stretching vibration bond of tri-s-triazine [48]. Vibration peaks between $1200-1650 \mathrm{~cm}^{-1}$ corresponds to the typical stretching modes of $\mathrm{CN}$ heterocycles [49]. A wider band can be seen at $3100-3300 \mathrm{~cm}^{-1}$, which belongs to the stretching vibration modes for the unreacted $-\mathrm{NH}$ [50]. The same characteristic peaks are observed in CDots $/ \mathrm{g}-\mathrm{C}_{3} \mathrm{~N}_{4}$ composite and the peak at $1405 \mathrm{~cm}^{-1}$ can be seen as the indicator for the coupling of $\mathrm{CDots}$ and $\mathrm{g}-\mathrm{C}_{3} \mathrm{~N}_{4}$ [48].

XRD patterns of $\mathrm{g}-\mathrm{C}_{3} \mathrm{~N}_{4}$ and CDots $/ \mathrm{g}-\mathrm{C}_{3} \mathrm{~N}_{4}$ are displayed in Figure 1B. The main diffraction peaks observed at $12.9^{\circ}$ and $27.5^{\circ}$ in both g- $\mathrm{C}_{3} \mathrm{~N}_{4}$ and CDots $/ \mathrm{g}-\mathrm{C}_{3} \mathrm{~N}_{4}$ composite are indexed to the (100) peak of the in-plane structure of tri-s-triszine unit and (002) crystal facets of the inter-layer stacking of aromatic segments [51,52]. The two patterns fit well with graphitic carbon nitride (JCPDS 87-1526) and no significant difference is observed, implying the low content of CDots in CDots $/ \mathrm{g}-\mathrm{C}_{3} \mathrm{~N}_{4}$ composite. However, it is remarkable that the difference in relative intensity, together with the shift observed in the (002) peak location from $27.51^{\circ}$ for $\mathrm{g}-\mathrm{C}_{3} \mathrm{~N}_{4}$ to $27.59^{\circ}$ for CDots $/ \mathrm{g}-\mathrm{C}_{3} \mathrm{~N}_{4}$, can be seen as the evidence of CDots introduction [45]. As can be seen in Figure 1C, the introduction of CDots in CDots $/ \mathrm{g}-\mathrm{C}_{3} \mathrm{~N}_{4}$ leads to a $20 \%$ increase (from 120.92 to $145.24 \mathrm{~m}^{2} / \mathrm{g}$ ) in specific surface area, which favors the decomposition of $\mathrm{H}_{2} \mathrm{O}_{2}$.

Figure 1D clearly shows the two-dimensional structure of $\mathrm{g}-\mathrm{C}_{3} \mathrm{~N}_{4}$ together with the embedding of CDots (the white circles). The close look of the CDots embedded in $\mathrm{g}-\mathrm{C}_{3} \mathrm{~N}_{4}$ matrix is given in Figure $1 \mathrm{E}$. The CDots are non-uniformly distributed, ranging from 2 to $10 \mathrm{~nm}$, which is in line with previous studies $[45,51,53]$.

From the results and analysis above, it can be confirmed that CDots have been successfully decorated in $\mathrm{g}-\mathrm{C}_{3} \mathrm{~N}_{4}$ and the inlay of CDots brings an improvement in specific surface area of the composite.

\subsection{Kinetic Study}

The effect of CDots content in the catalyst has been investigated in several previous works proving that a certain amount of CDots can enhance the catalytic properties of the catalysts while an excessive loading may work opposite $[45,51,53]$. Thus, in this work the CDots $/ g-C_{3} \mathrm{~N}_{4}$ composite was fabricated with a fixed fraction of CDots (1.26 wt.\%) selected by preliminary experiments. It is known that the surface reaction is dominating in the present heterogeneous system, therefore surface area to solution volume ratio (SA/V) is used to represent the dosage of the composites other than the mass concentration, which has been applied in many reported works $[17,18,22,27,28,54-56]$. The SA/V value is obtained by combining the mass concentration $(\mathrm{g} / \mathrm{L})$ with specific surface area $\left(\mathrm{m}^{2} / \mathrm{g}\right)$ and can be normalized to $\mathrm{m}^{-1}$. 
To verify the synergistic effect of CDots and $g-\mathrm{C}_{3} \mathrm{~N}_{4}$ in $\mathrm{H}_{2} \mathrm{O}_{2}$ decomposition, five samples were prepared according to the proportion of CDots and g- $\mathrm{C}_{3} \mathrm{~N}_{4}$ in the composite. Sample 5 is the CDots $/ \mathrm{g}-\mathrm{C}_{3} \mathrm{~N}_{4}$ composite with SA/V of $4 \times 10^{5} \mathrm{~m}^{-1}$. The pure $\mathrm{g}-\mathrm{C}_{3} \mathrm{~N}_{4}$ with the same SA/V value was identified as Sample 2. The single-component CDots solution containing the equivalent amount of CDots as Sample 5 $(13.4 \mathrm{mg} / \mathrm{L})$ was named as Sample 1 and it was obtained by directly diluting the originally prepared CDots solution. The physical mixture of Sample 1 and 2 is identified as Sample 3. Additionally, the originally prepared CDots solution with a high concentration $(133 \mathrm{mg} / \mathrm{L})$ was named as Sample 4 .

Detailed descriptions of the samples are listed in Table 1. It should be noted that sample 1, 3 and 5 has equivalent amount of CDots and sample 3 is a simple mixture of CDots and g- $\mathrm{C}_{3} \mathrm{~N}_{4}$ while sample 5 is the composite. The catalytic decomposition of $\mathrm{H}_{2} \mathrm{O}_{2}$ by each sample was investigated under the same experimental condition where initial concentration of $\mathrm{H}_{2} \mathrm{O}_{2}\left(\left[\mathrm{H}_{2} \mathrm{O}_{2}\right]_{0}\right)$ is $0.5 \mathrm{mM}$ and the temperature is $298 \mathrm{~K}$. Normalized concentration of $\mathrm{H}_{2} \mathrm{O}_{2}\left(\left[\mathrm{H}_{2} \mathrm{O}_{2}\right] /\left[\mathrm{H}_{2} \mathrm{O}_{2}\right]_{0}\right)$ of each case is plotted against reaction time respectively (shown in Figure 2).

Table 1. Samples prepared for the investigation of synergistic effect of CDots and g- $\mathrm{C}_{3} \mathrm{~N}_{4}$.

\begin{tabular}{cc}
\hline Sample & Description \\
\hline $\mathbf{1}$ & $13.4 \mathrm{mg} / \mathrm{L} \mathrm{CDots}$ \\
$\mathbf{2}$ & $4 \times 10^{5} \mathrm{~m}^{-1} \mathrm{~g}-\mathrm{C}_{3} \mathrm{~N}_{4}$ \\
$\mathbf{3}$ & physical mixture of Sample 1 and Sample 2 \\
$\mathbf{4}$ & $133 \mathrm{mg} / \mathrm{L} \mathrm{CDots}$ \\
$\mathbf{5}$ & $4 \times 10^{5} \mathrm{~m}^{-1} \mathrm{CDots} / \mathrm{g}-\mathrm{C}_{3} \mathrm{~N}_{4}$ composite \\
\hline
\end{tabular}

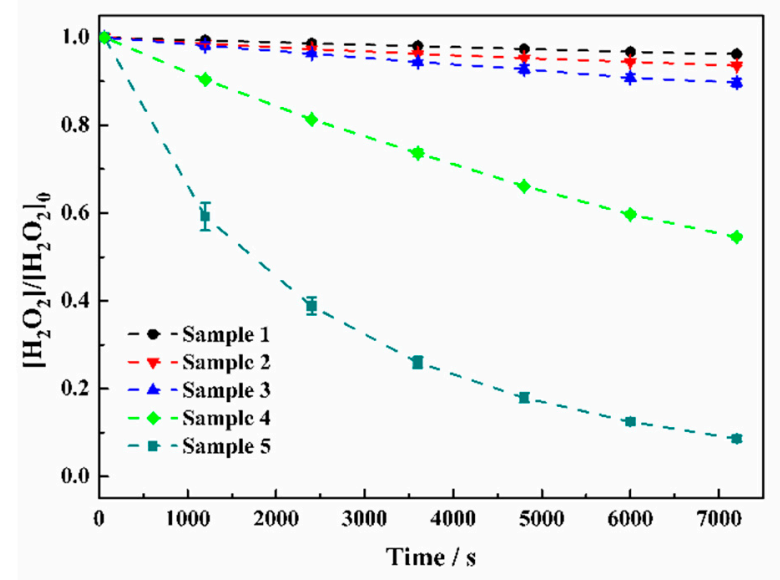

Figure 2. $\left[\mathrm{H}_{2} \mathrm{O}_{2}\right] /\left[\mathrm{H}_{2} \mathrm{O}_{2}\right]_{0}\left(\left[\mathrm{H}_{2} \mathrm{O}_{2}\right]_{0}=0.5 \mathrm{mM}\right)$ as a function of reaction time in the presence of sample $1-5$ at $298 \mathrm{~K}$.

As shown in Figure 2, Sample 4 (the originally prepared CDots, $133 \mathrm{mg} / \mathrm{L}$ ) incurs a gradely decline in $\mathrm{H}_{2} \mathrm{O}_{2}$ concentration in darkness, demonstrating the inherent catalytic property of CDots for $\mathrm{H}_{2} \mathrm{O}_{2}$ decomposition. However, the catalytic performance becomes faint after diluting CDots to a $10.2 \%$ concentration when comparing sample 1 and 4 , indicating that such catalysis process is strongly dependent on the applied CDots concentration, which is in accordance with reported work [57]. Sample 2 (pure g- $\mathrm{C}_{3} \mathrm{~N}_{4}$ ) also incurs slight decline in $\mathrm{H}_{2} \mathrm{O}_{2}$, which can be attributed to the adsorption of g- $\mathrm{C}_{3} \mathrm{~N}_{4}$ and catalytic decomposition by carbon-based material through the delocalization of electrons on the surface [24]. However, the decomposition of $\mathrm{H}_{2} \mathrm{O}_{2}$ catalyzed by the pure g- $\mathrm{C}_{3} \mathrm{~N}_{4}$ should not be considered as the main process in the system with CDots/g- $\mathrm{C}_{3} \mathrm{~N}_{4}$ composite. It is remarkable that the consumption rate of $\mathrm{H}_{2} \mathrm{O}_{2}$ for sample 5 is much larger than sample 3, implying the thermal polymerization process gives rise to the remarkable synergy and the proximity between the CDots and the adsorption sites of $\mathrm{H}_{2} \mathrm{O}_{2}$ in $\mathrm{g}-\mathrm{C}_{3} \mathrm{~N}_{4}$ is necessary for the high efficiency of $\mathrm{H}_{2} \mathrm{O}_{2}$ decomposition [44]. 
It has been previously reported that $[18,54]$, the catalytic decomposition of $\mathrm{H}_{2} \mathrm{O}_{2}$ in the heterogeneous system follows pseudo first-order kinetics with respect to $\mathrm{H}_{2} \mathrm{O}_{2}$ when solid is excess to $\mathrm{H}_{2} \mathrm{O}_{2}$ and the reaction rate equation can be described as $\frac{-\mathrm{d}\left[\mathrm{H}_{2} \mathrm{O}_{2}\right]}{\mathrm{dt}}=\mathrm{k}_{1} \times\left[\mathrm{H}_{2} \mathrm{O}_{2}\right]$, which can be integrated as

$$
\ln \frac{\left[\mathrm{H}_{2} \mathrm{O}_{2}\right]}{\left[\mathrm{H}_{2} \mathrm{O}_{2}\right]_{0}}=-\mathrm{k}_{1} \mathrm{t}
$$

where $\mathrm{k}_{1}$ is the pseudo first-order rate constant at a given temperature and dosage of the solid, $\mathrm{t}$ is the reaction time, $\left[\mathrm{H}_{2} \mathrm{O}_{2}\right]$ is the concentration of $\mathrm{H}_{2} \mathrm{O}_{2}$ at a time and $\left[\mathrm{H}_{2} \mathrm{O}_{2}\right]_{0}$ is the concentration of $\mathrm{H}_{2} \mathrm{O}_{2}$ at $\mathrm{t}=0$. When the solid catalyst is excess to $\mathrm{H}_{2} \mathrm{O}_{2}$, the second-order rate constant in the system can be determined by studying the pseudo first-order rate constant $\left(\mathrm{k}_{1}\right)$ as a function of SA/V (surface area of solid to volume of solution). The second-order rate expression is given as

$$
\frac{-\mathrm{d}\left[\mathrm{H}_{2} \mathrm{O}_{2}\right]}{\mathrm{dt}}=\mathrm{k}_{2} \times \frac{\mathrm{SA}}{\mathrm{V}} \times\left[\mathrm{H}_{2} \mathrm{O}_{2}\right]
$$

where $\mathrm{k}_{2}$ denotes the second-order reaction rate constant, SA denotes the surface area of the CDots $/ \mathrm{g}-\mathrm{C}_{3} \mathrm{~N}_{4}$ and $\mathrm{V}$ is the volume of the reaction solution. The term SA/V has been applied to denote the catalyst concentration in a number of studies regarding the heterogeneous catalysis system $[18,22,27,54]$.

According to the preliminary experiments, the lower limit of SA/V is $3.2 \times 10^{5} \mathrm{~m}^{-1}$ after which it is excess to the fixed initial $\mathrm{H}_{2} \mathrm{O}_{2}$ concentration $(0.5 \mathrm{mM})$. A series of experiments were carried out by varying the dosage of catalyst (SA/V) from 3.2 to $6.4 \times 10^{5} \mathrm{~m}^{-1}$ under the same condition at $298 \mathrm{~K}$ to explore the kinetics of the present system. The logarithm of normalized $\mathrm{H}_{2} \mathrm{O}_{2}$ concentration is plotted as a function of reaction time (Figure $3 \mathrm{~A}$ ) and the slope of the linearly fitted curve of these plots $\left(\mathrm{k}_{1}\right)$ is plotted against SA/V accordingly (Figure 3B).
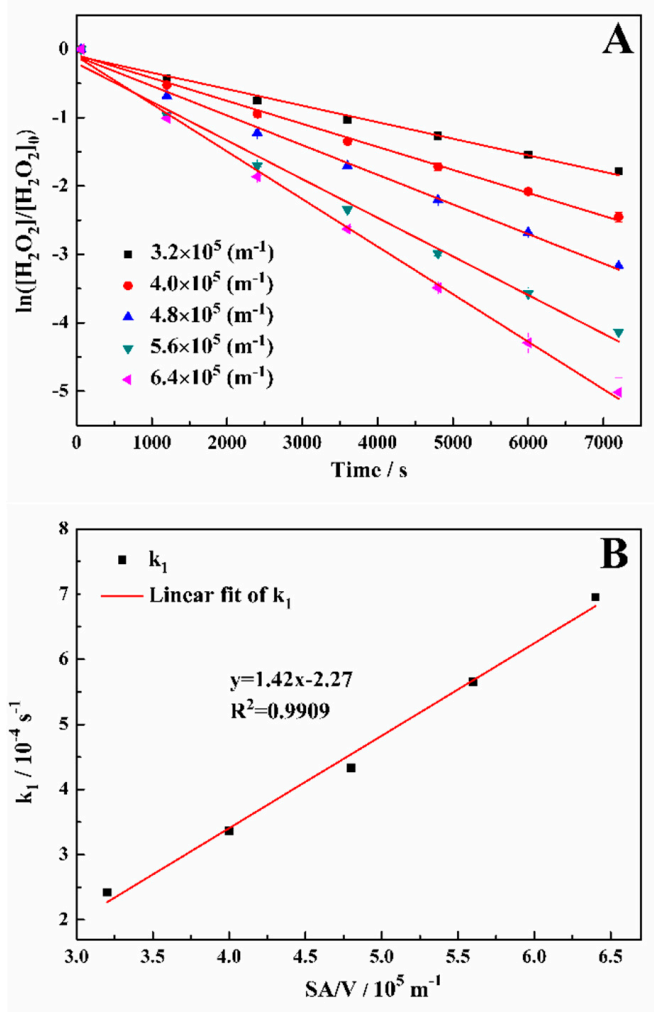

Figure 3. (A) $\ln \left(\left[\mathrm{H}_{2} \mathrm{O}_{2}\right] /\left[\mathrm{H}_{2} \mathrm{O}_{2}\right]_{0}\right)\left(\left[\mathrm{H}_{2} \mathrm{O}_{2}\right]_{0}=0.5 \mathrm{mM}\right)$ as a function of reaction time with different SA/V values of catalyst $\left(3.2-6.4 \times 10^{5} \mathrm{~m}^{-1}\right)$ at $298 \mathrm{~K}$; (B) pseudo first-order reaction rate constant as a function of SA/V at $298 \mathrm{~K}$. The $\mathrm{k}_{1}$ values were obtained from Figure $3 \mathrm{~A}$. 
From Figure 3A, it can be seen that all the $\ln \left(\left[\mathrm{H}_{2} \mathrm{O}_{2}\right] /\left[\mathrm{H}_{2} \mathrm{O}_{2}\right]_{0}\right)$ plots are linearly fitted with reaction time which indicates it follows pseudo first-order kinetics at given dosage of the composite and the slopes of the fitted curves are denoted as $k_{1}$. In addition, it is clearly that the observed decomposition rate of $\mathrm{H}_{2} \mathrm{O}_{2}$ increases with increasing the dosage of the composite. The key parameters of the fitted curves, including SA/V, slopes $\left(\mathrm{k}_{1}\right)$, standard deviation and $\mathrm{R}^{2}$, are listed in Table 2.

Table 2. The key parameters of the fitted curves with different SA/V values.

\begin{tabular}{|c|c|c|c|}
\hline $\mathrm{SA} / \mathrm{V}\left(10^{5} \mathrm{~m}^{-1}\right)$ & $k_{1}\left(10^{-4} s^{-1}\right)$ & Standard Deviation $\left(10^{-4} s^{-1}\right)$ & $R^{2}(\%)$ \\
\hline 3.2 & 2.61 & 0.078 & 99.38 \\
\hline 4.0 & 3.52 & 0.068 & 99.74 \\
\hline 4.8 & 4.53 & 0.084 & 99.76 \\
\hline 5.6 & 6.05 & 1.063 & 99.49 \\
\hline 6.4 & 7.16 & 0.094 & 99.88 \\
\hline
\end{tabular}

The obtained $k_{1}$ values from Table 2 were plotted in Figure 3B against SA/V. As can be seen from Figure $3 \mathrm{~B}, \mathrm{k}_{1}$ is linearly correlated to $\mathrm{SA} / \mathrm{V}$ in the range of $3.2-6.4 \times 10^{5} \mathrm{~m}^{-1}$ and the slope of the fitted curve is calculated as $(1.42 \pm 0.07) \times 10^{-9} \mathrm{~m} \cdot \mathrm{s}^{-1}$ which can be denoted as the overall second-order rate constant. This value is far from the rate constant of a diffusion controlled reaction in the order of $10^{-5} \mathrm{~m} \cdot \mathrm{s}^{-1}$ but still higher than some metal oxide catalysts like $\mathrm{ZrO}_{2}\left((2.39 \pm 0.09) \times 10^{-10} \mathrm{~m} \cdot \mathrm{s}^{-1}\right)$, $\mathrm{CuO}\left((1.23 \pm 0.06) \times 10^{-9} \mathrm{~m} \cdot \mathrm{s}^{-1}\right)$ and $\mathrm{Gd}_{2} \mathrm{O}_{3}\left((9.4 \pm 1.0) \times 10^{-10} \mathrm{~m} \cdot \mathrm{s}^{-1}\right)[18,54]$.

Generally, the first-order rate constant $\mathrm{k}_{1}$ is strongly related to the reaction temperature according to the Arrhenius equation:

$$
\mathrm{k}_{1}=\mathrm{Ae}^{-\mathrm{E}_{\mathrm{a}} / \mathrm{RT}}
$$

where $E_{a}$ denotes the activation energy for the reaction, $R$ is the gas constant, $T$ is the absolute temperature and $\mathrm{A}$ is the pre-exponential factor. The logarithm of $\mathrm{k}_{1}$ obtained by plotting $\ln \left(\left[\mathrm{H}_{2} \mathrm{O}_{2}\right] /\left[\mathrm{H}_{2} \mathrm{O}_{2}\right]_{0}\right)$ against $\mathrm{T}$ (shown in Figure $4 \mathrm{~A}$ ) is plotted as a function of $1 / \mathrm{T}$ in Figure $4 \mathrm{~B}$ so as to calculate $\mathrm{E}_{\mathrm{a}}$.

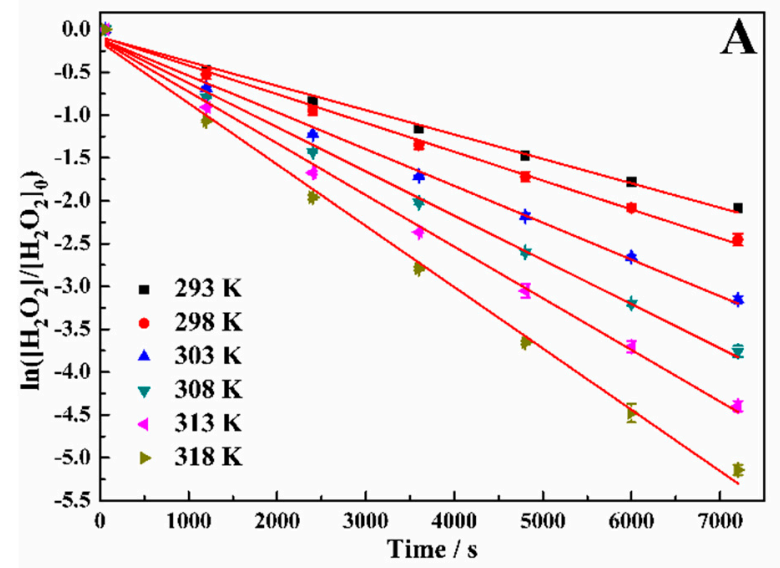

Figure 4. Cont. 


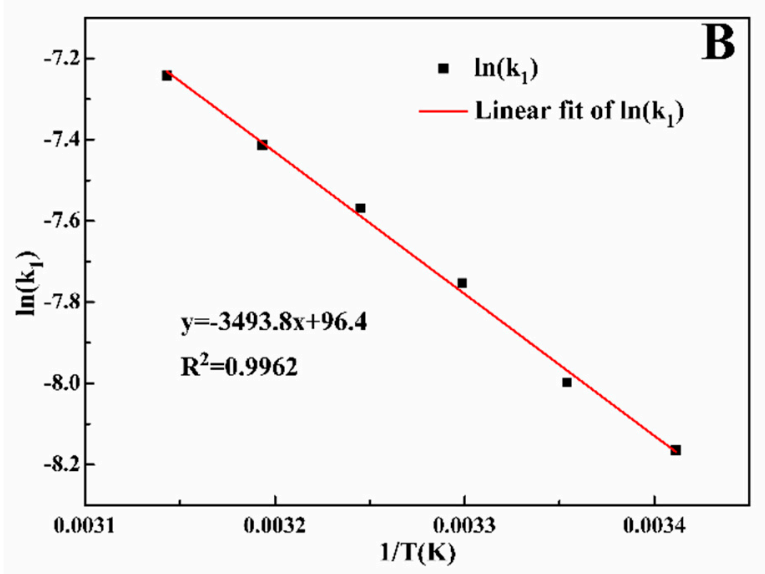

Figure 4. (A) $\ln \left(\left[\mathrm{H}_{2} \mathrm{O}_{2}\right] /\left[\mathrm{H}_{2} \mathrm{O}_{2}\right]_{0}\right)\left(\left[\mathrm{H}_{2} \mathrm{O}_{2}\right]_{0}=0.5 \mathrm{mM}\right)$ as a function of reaction time at different reaction temperatures $(293-318 \mathrm{~K})$ with the catalyst dosage of $4.0 \times 10^{5} \mathrm{~m}^{-1} ;(\mathbf{B}) \ln \left(\mathrm{k}_{1}\right)$ as a function of $(1 / \mathrm{T})$ where $\mathrm{k}_{1}$ were obtained from Figure $4 \mathrm{~A}$.

As shown in Figure $4 \mathrm{~A}, \ln \left(\left[\mathrm{H}_{2} \mathrm{O}_{2}\right] /\left[\mathrm{H}_{2} \mathrm{O}_{2}\right]_{0}\right)$ declines with reaction time and the slope of the fitted curves increases as temperature increases. In addition, $\ln \left(\left[\mathrm{H}_{2} \mathrm{O}_{2}\right] /\left[\mathrm{H}_{2} \mathrm{O}_{2}\right]_{0}\right)$ drops sharply in the initial period ( $20 \mathrm{~min}$ ) indicating the adsorption dominates this period, after which adsorbed $\mathrm{H}_{2} \mathrm{O}_{2}$ on the surface of the CDots/g- $\mathrm{C}_{3} \mathrm{~N}_{4}$ composite reaches an equilibrium state and the decomposition of $\mathrm{H}_{2} \mathrm{O}_{2}$ catalyzed by embedded CDots turns the dominant role.

It can be seen from Figure $4 \mathrm{~B}, \ln \left(\mathrm{k}_{1}\right)$ is linearly dependent on $1 / \mathrm{T}$ and the slope of the fitted curve is obtained. Based on the slope, the activation energy of the reaction is calculated to be $(29.05 \pm 0.80)$ $\mathrm{kJ} \cdot \mathrm{mol}^{-1}$, which is to some extent lower than a series of metal oxides developed before, including $\mathrm{ZrO}_{2}$ $\left((33 \pm 1) \mathrm{kJ} \cdot \mathrm{mol}^{-1}\right), \mathrm{TiO}_{2}\left((37 \pm 1) \mathrm{kJ} \cdot \mathrm{mol}^{-1}\right), \mathrm{Y}_{2} \mathrm{O}_{3}\left((47 \pm 5) \mathrm{kJ} \cdot \mathrm{mol}^{-1}\right), \mathrm{Fe}_{2} \mathrm{O}_{3}\left((47 \pm 1) \mathrm{kJ} \cdot \mathrm{mol}^{-1}\right)$, $\mathrm{CuO}\left((76 \pm 1) \mathrm{kJ} \cdot \mathrm{mol}^{-1}\right), \mathrm{CeO}_{2}\left((40 \pm 1) \mathrm{kJ} \cdot \mathrm{mol}^{-1}\right), \mathrm{Gd}_{2} \mathrm{O}_{3}\left((63 \pm 1) \mathrm{kJ} \cdot \mathrm{mol}^{-1}\right)$ and $\mathrm{HfO}_{2}((60 \pm 1)$ $\left.\mathrm{kJ} \cdot \mathrm{mol}^{-1}\right)[18,54,58]$.

The key parameters of the fitted curves, including $\mathrm{T}$, pseudo first-order reaction rate constants $\left(\mathrm{k}_{1}\right)$, standard deviation and $\mathrm{R}^{2}$, are listed in Table 3.

Table 3. The key parameters of the fitted curves with different temperatures.

\begin{tabular}{|c|c|c|c|}
\hline $\mathrm{T}(\mathrm{K})$ & $k_{1}\left(10^{-4} s^{-1}\right)$ & Standard Deviation $\left(10^{-4} \mathrm{~s}^{-1}\right)$ & $R^{2}(\%)$ \\
\hline 293 & 3.02 & 0.071 & 99.61 \\
\hline 298 & 3.52 & 0.068 & 99.74 \\
\hline 303 & 4.50 & 0.088 & 99.74 \\
\hline 308 & 5.37 & 0.090 & 99.80 \\
\hline 313 & 6.27 & 0.104 & 99.81 \\
\hline 318 & 7.44 & 0.129 & 99.80 \\
\hline
\end{tabular}

\subsection{The Effect of $p H$}

To investigate the mechanism of the present system containing $\mathrm{H}_{2} \mathrm{O}_{2}$ and CDots/g- $\mathrm{C}_{3} \mathrm{~N}_{4}$ composite, it is significant to study the $\mathrm{pH}$ effect as well as quantify the in-situ produced hydroxyl radicals. Due to its scavenging capacity against $\mathrm{HO}$. and $\mathrm{pH}$ buffering ability, Tris is chosen to carry out the mechanistic study. The pKa and the buffering range of Tris are 8.07 and 7.0-9.0 respectively, so the $\mathrm{pH}$ values were selected within this range. The decline of $\mathrm{H}_{2} \mathrm{O}_{2}$ together with the production of $\mathrm{CH}_{2} \mathrm{O}$ against the reaction time with different $\mathrm{pH}$ are exhibited in Figure 5 . 


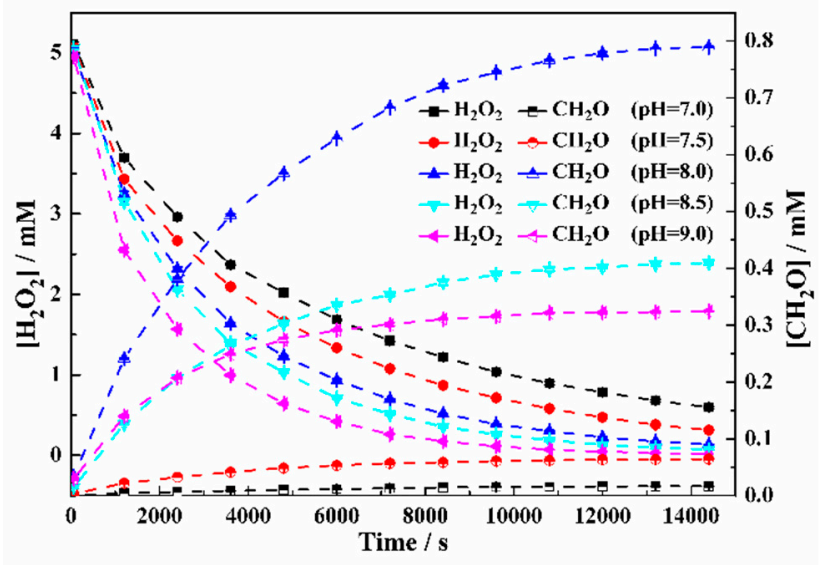

Figure 5. The concentration of $\mathrm{H}_{2} \mathrm{O}_{2}\left(\left[\mathrm{H}_{2} \mathrm{O}_{2}\right]_{0}=5 \mathrm{mM}\right)$ and $\mathrm{CH}_{2} \mathrm{O}$ as a function of reaction time in the presence of Tris $\left([\text { Tris }]_{0}=100 \mathrm{mM}\right.$ ) with the catalyst dosage of $4.0 \times 10^{5} \mathrm{~m}^{-1}$ at $298.15 \mathrm{~K}$ in $\mathrm{pH}$ from 7.0 to 9.0 .

It can be clearly seen in Figure 5 that the decomposition rate of $\mathrm{H}_{2} \mathrm{O}_{2}$ increases with $\mathrm{pH}$ increases in the whole range. However, the formation of $\mathrm{CH}_{2} \mathrm{O}$ shows a different trend. The evolution of $\mathrm{CH}_{2} \mathrm{O}$ remains relatively low in neutral condition ( $\mathrm{pH} 7.0$ ), then it starts to accelerate until $\mathrm{pH} 8.0$, after which the formation rate of $\mathrm{CH}_{2} \mathrm{O}$ declines as $\mathrm{pH}$ increases. This indicates that the formation of $\mathrm{CH}_{2} \mathrm{O}$ and probably the production of $\mathrm{HO}$ - are alkaline favored while the production is to some degree related to the pKa of Tris [54].

To figure out whether the production of $\mathrm{HO}$. is also $\mathrm{pH}$ dependent, it is necessary to introduce the yield $(\mathrm{Y})$ of $\mathrm{CH}_{2} \mathrm{O}$ formed by $\mathrm{HO}$ - and Tris. $\mathrm{Y}$ is defined by the equation:

$$
\mathrm{Y}=\left[\mathrm{CH}_{2} \mathrm{O}\right] /[\mathrm{HO} \cdot]
$$

where [HO-] is the production of $\mathrm{HO} \cdot$ and $\left[\mathrm{CH}_{2} \mathrm{O}\right]$ is the accumulated $\mathrm{CH}_{2} \mathrm{O}$ in $\mathrm{H}_{2} \mathrm{O}_{2}$ decomposition experiment. According to a previous study using $\gamma$-radiation in homogeneous system [17], the yield (Y) of $\mathrm{CH}_{2} \mathrm{O}$ increases from $25 \%$ to $51 \%$ as increasing $\mathrm{pH}$ from 7.0 to 9.0. Provided that the yield (Y) in heterogeneous system is consistent with that in homogeneous system, the production of $\mathrm{HO}$. in $\mathrm{H}_{2} \mathrm{O}_{2}$ decomposition on CDots/g- $\mathrm{C}_{3} \mathrm{~N}_{4}$ composite can be estimated by this value together with the final concentration of $\mathrm{CH}_{2} \mathrm{O}$. The results are shown in Figure 6.

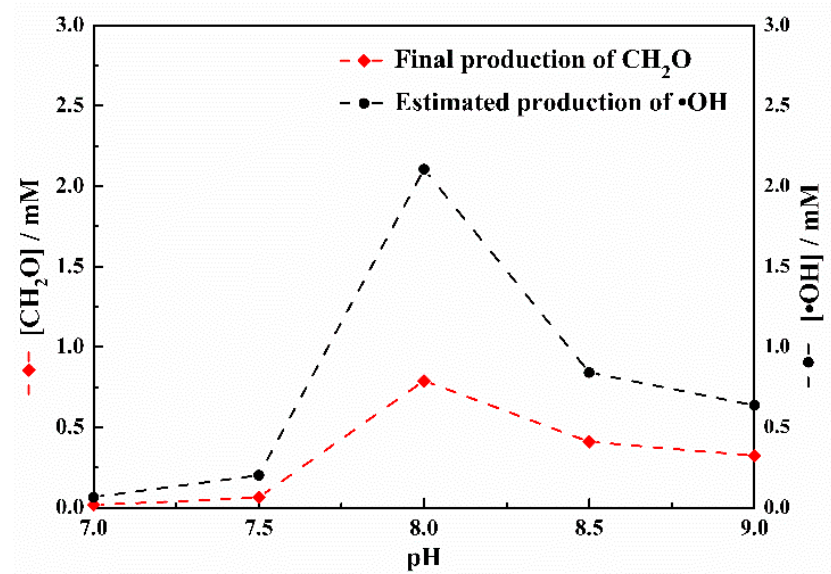

Figure 6. Final production of $\mathrm{CH}_{2} \mathrm{O}$ and estimated production of $\mathrm{HO}$ - as a function of $\mathrm{pH}$. The final productions of $\mathrm{CH}_{2} \mathrm{O}$ were extracted from Figure 5. The estimated [HO· $]=\left[\mathrm{CH}_{2} \mathrm{O}\right] / \mathrm{Y}$ and the yields (Y) were derived from a previous work [17]. 
As appeared in Figure 6, the plots of estimated production of HO- exhibit the similar tendency as that of final production of $\mathrm{CH}_{2} \mathrm{O}$ and it still peaks at $\mathrm{pH} 8.0$ with the maximum concentration of $2.10 \mathrm{mM}\left([\mathrm{HO} \cdot]=\left[\mathrm{CH}_{2} \mathrm{O}\right] / \mathrm{Y}\right.$ where $\mathrm{Y}=37.5 \%$ at $\left.\mathrm{pH} 8.0\right)$. This means the stoichiometry between $\mathrm{H}_{2} \mathrm{O}_{2}$ and $\mathrm{CH}_{2} \mathrm{O}$ is approximately $1: 0.158$ and $42.1 \%$ of $\mathrm{H}_{2} \mathrm{O}_{2}\left(\left[\mathrm{H}_{2} \mathrm{O}_{2}\right]_{0}=5 \mathrm{mM}\right.$, Tris is excess to $\mathrm{H}_{2} \mathrm{O}_{2}$ ) end up with $\mathrm{HO}$. at the optimal $\mathrm{pH}$. The efficiency of $\mathrm{H}_{2} \mathrm{O}_{2}$ consumption towards $\mathrm{HO}$. is much higher as compared to that of the $\mathrm{H}_{2} \mathrm{O}_{2} / \mathrm{ZrO}_{2} /$ Tris system (13.4\% at pH 8.0) [17]. Therefore, it can be concluded that the production of $\mathrm{HO}$. is also $\mathrm{pH}$-dependent and there is an optimal $\mathrm{pH}$ which may have something to do with the Tris [22].

Based on the results in present work, the intrinsic chemical catalytic properties of the synthesized CDots $/ g-C_{3} \mathrm{~N}_{4}$ composite, other than the photocatalytic properties, have been revealed to some extent. The hypothesis in the introduction section could be confirmed as following: firstly, as demonstrated in Figure 2, the pure CDots synthesized via an electrochemical pathway showed excellent catalytic ability, in line with the literature [59]; secondly, similar as the reported property of g- $\mathrm{C}_{3} \mathrm{~N}_{4}$ [60], Figure 2 also shows that the concentration of $\mathrm{H}_{2} \mathrm{O}_{2}$ in the solution decreases slightly in the presence of the pure $\mathrm{g}-\mathrm{C}_{3} \mathrm{~N}_{4}$ which indicates g- $\mathrm{C}_{3} \mathrm{~N}_{4}$ does provide sufficient reaction site for $\mathrm{H}_{2} \mathrm{O}_{2}$ to adsorb; thirdly, by analyzing the results in Figures 2, 3, 5 and 6, it is known that hydroxyl radical can be formed during the decomposition of $\mathrm{H}_{2} \mathrm{O}_{2}$ catalyzed by the CDots/g- $\mathrm{C}_{3} \mathrm{~N}_{4}$ composite in the heterogeneous system as hypothesized in the former section. Besides the strong affinity of g- $\mathrm{C}_{3} \mathrm{~N}_{4}$ towards $\mathrm{H}_{2} \mathrm{O}_{2}$ and the catalytic property of CDots against the adsorbed $\mathrm{H}_{2} \mathrm{O}_{2}$ [47], the delocalization of the electrons on the surface of $\mathrm{g}-\mathrm{C}_{3} \mathrm{~N}_{4}$ may also leads to the decomposition of $\mathrm{H}_{2} \mathrm{O}_{2}$ via electron-transfer mechanism [24]. In conclusion, the synthesized CDots/g- $\mathrm{C}_{3} \mathrm{~N}_{4}$ composite exhibits the synergy of adsorption of $\mathrm{H}_{2} \mathrm{O}_{2}$ and delocalization of electrons on g- $\mathrm{C}_{3} \mathrm{~N}_{4}$ and catalytic decomposition of $\mathrm{H}_{2} \mathrm{O}_{2}$ by g- $\mathrm{C}_{3} \mathrm{~N}_{4}$ and CDots producing hydroxyl radicals.

Based on the results and discussion above, the mechanism of catalytic decomposition of $\mathrm{H}_{2} \mathrm{O}_{2}$ in the heterogeneous system with CDots $/ \mathrm{g}-\mathrm{C}_{3} \mathrm{~N}_{4}$ composite is proposed and illustrated in Figure 7.

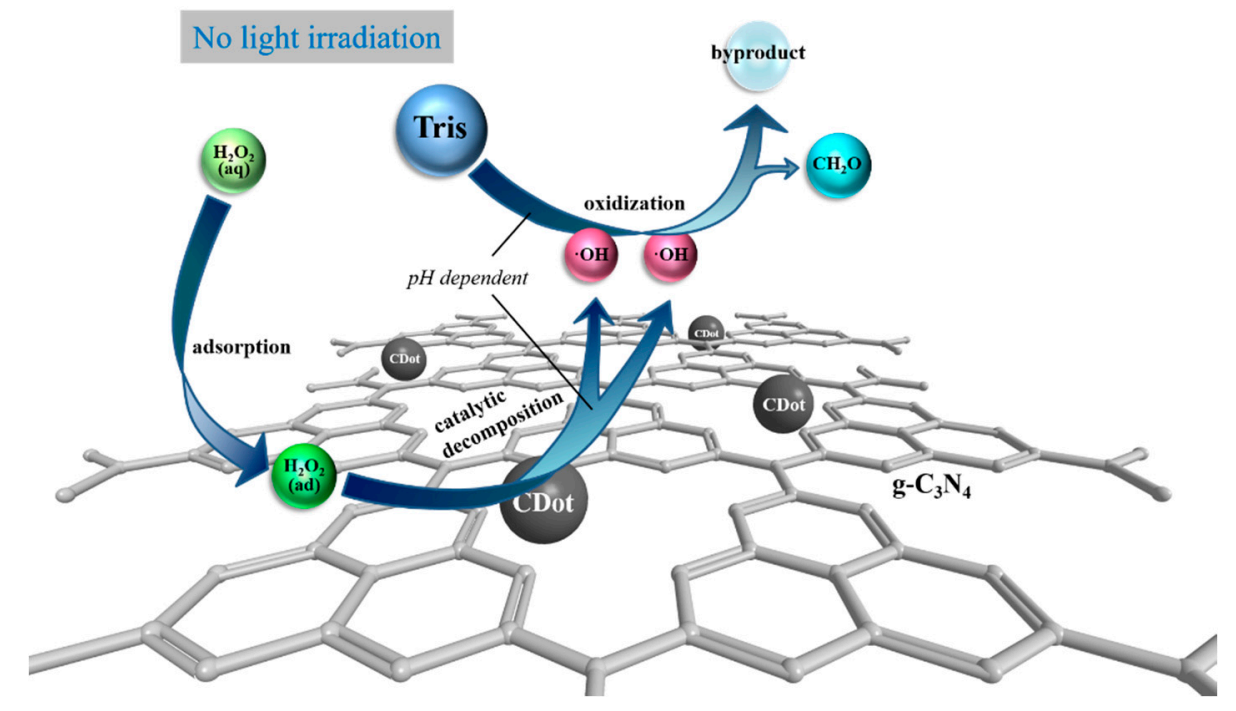

Figure 7. The mechanism of catalytic decomposition of $\mathrm{H}_{2} \mathrm{O}_{2}$ on CDots/g- $\mathrm{C}_{3} \mathrm{~N}_{4}$ composite.

Key of the mechanism is the so-called adsorb-catalyze double reaction sites. With plenty of accessible adsorption sites on the surface of g- $\mathrm{C}_{3} \mathrm{~N}_{4}, \mathrm{CDots} / \mathrm{g}-\mathrm{C}_{3} \mathrm{~N}_{4}$ composite shows high selective adsorption ability towards aqueous $\mathrm{H}_{2} \mathrm{O}_{2}$. From previous works studying similar heterogeneous system with $\mathrm{H}_{2} \mathrm{O}_{2}$ and solid catalyst $[18,22,54]$, it is known that $\mathrm{H}_{2} \mathrm{O}_{2}$ concentration exhibits an initial drop indicating the adsorption on the surface of catalyst, after which the $\mathrm{H}_{2} \mathrm{O}_{2}$ decomposition obeys pseudo first-order kinetic when the surface reaches equilibrium state. As can be seen in Figure 3A, the $\mathrm{H}_{2} \mathrm{O}_{2}$ concentration follows the similar trend and kinetics. Hence, it can be demonstrated that the adsorption of $\mathrm{H}_{2} \mathrm{O}_{2}$ is also dominating in the initial short period. Tris was introduced 
in the present work as a probe of hydroxyl radical and $\mathrm{pH}$ buffer. It is known that Tris can be partially oxidized to $\mathrm{CH}_{2} \mathrm{O}$ and other byproducts and the ratio between the concentration of hydroxyl radicals and formed $\mathrm{CH}_{2} \mathrm{O}$ is relatively fixed under given condition $(\mathrm{pH}$ and dissolved oxygen concentration) $[17,27]$. Therefore, the formation of $\mathrm{CH}_{2} \mathrm{O}$ can be used to probe the formed hydroxyl radicals in the heterogeneous system containing $\mathrm{H}_{2} \mathrm{O}_{2}$ and CDots $/ \mathrm{g}-\mathrm{C}_{3} \mathrm{~N}_{4}$ composite. It is in line with previous works that $[17,18,22,27], \mathrm{CH}_{2} \mathrm{O}$ formation is reflected by the decomposition of $\mathrm{H}_{2} \mathrm{O}_{2}$ and is pH-dependent (Figures 5 and 6). Hence, it can be deduced that after the initial period, the adsorbed $\mathrm{H}_{2} \mathrm{O}_{2}$ on the surface of the CDots/g- $\mathrm{C}_{3} \mathrm{~N}_{4}$ composite reaches an equilibrium state and the decomposition of $\mathrm{H}_{2} \mathrm{O}_{2}$ catalyzed by embedded CDots on the surface sites turns the dominant role. During this procedure, large quantities of $\mathrm{HO}$ - was produced, exhibiting strong oxidation ability towards scavengers like Tris. It should be noted that the production of $\mathrm{HO}$ - is strongly $\mathrm{pH}$ dependent. To sum up, the CDots / $\mathrm{g}-\mathrm{C}_{3} \mathrm{~N}_{4}$ composite shows synergetic effect on the decomposition of $\mathrm{H}_{2} \mathrm{O}_{2}$ via adsorb-catalyze double reaction sites and more importantly, is proved to be a promising catalyst for the degradation of NBDOPs since it is a metal-free pathway of producing HO- efficiently.

\section{Experimental Section}

\subsection{Instrumentation}

The morphology and microstructure of samples were observed by JET-2100F (JEOL, Wuhan, China) transmission electron microscope (TEM). The Fourier transform infrared spectroscopy (FTIR) of the samples were recorded by Nicolet iS5 (Thermo Fisher Scientific, Wuhan, China) FTIR spectrometer with $\mathrm{KBr}$ pellets. The specific surface area of CDots $/ g-C_{3} \mathrm{~N}_{4}$ composite and pure $\mathrm{g}-\mathrm{C}_{3} \mathrm{~N}_{4}$ were determined by the Brunauer-Emmett-Teller (B.E.T) method via isothermal adsorption and desorption of high purity nitrogen using a TriStar II 3020 (Micromeritics, Wuhan, China) instrument. X-ray diffraction (XRD) patterns were recorded with D8 advance (Bruker, Wuhan, China) diffractometer using Bragg-Brentano geometry in the $2 \theta$ angle from $10^{\circ}$ to $40^{\circ}$ and $\mathrm{Cu} \mathrm{K} \alpha$ irradiation $(\lambda=1.54 \AA$ ). The samples were weighted to $\pm 10^{-4} \mathrm{~g}$ in a ME104E (Mettler Toledo, Wuhan, China) microbalance. UV/Vis spectra were collected by V-5600 (METASH, Wuhan, China) and UV-5500PC (METASH, Wuhan, China) spectrophotometer. The $\mathrm{pH}$ of reaction solution was measured by PHS-3C (YOKE, Wuhan, China) $\mathrm{pH}$ meter with an accuracy of $\pm 0.01 \mathrm{pH}$ units.

\subsection{Reagents and Experiments}

All the solutions used in this study were prepared using deionized water.

Preparation of the catalyst: CDots were synthesized via an electrochemical method based on previous reported work [59]. In a typical preparation process, two graphite rods were insert parallel into $300 \mathrm{~mL}$ ultrapure water as electrodes with a separation of $7.5 \mathrm{~cm}$ and $4 \mathrm{~cm}$ depth under water. $60 \mathrm{~V}$ static potentials were applied to the rods by a direct-current (DC). After electrolyzing for $120 \mathrm{~h}$, the anode graphite rod corroded and a dark brown solution was formed. The solution was filtered with slow-speed quantitative filter paper and then centrifuged at 10,000 rpm for $10 \mathrm{~min}$. Finally, the soluble CDots was obtained and the concentration can be quantified by drying and weighting.

A thermal polymerization method was applied for the synthesis of pure $g-\mathrm{C}_{3} \mathrm{~N}_{4}$ [61]. Typically, 40 g urea (CAS[57-13-6], 99\%, Sinopharm, Wuhan, China) was dissolved in $40 \mathrm{~mL}$ ultrapure water in a quartz crucible, then heated to $550{ }^{\circ} \mathrm{C}$ with the rate of $7{ }^{\circ} \mathrm{C} / \mathrm{min}$ in a muffle furnace and kept at $550^{\circ} \mathrm{C}$ for $2 \mathrm{~h}$. After naturally cooling down to room temperature, the resultant yellow product was collected and ground into powder to obtain pure g- $\mathrm{C}_{3} \mathrm{~N}_{4}$. CDots $/ \mathrm{g}-\mathrm{C}_{3} \mathrm{~N}_{4}$ composite was synthesized via in-situ thermal polymerization [51]. Following the same procedure, $40 \mathrm{~g}$ urea was dissolved in $40 \mathrm{~mL}$ CDots solution and calcined in muffle furnace. The dark gray product CDots $/ \mathrm{g}-\mathrm{C}_{3} \mathrm{~N}_{4}$ was collected and ground for further use.

Kinetic studies: Hydrogen peroxide $\mathrm{H}_{2} \mathrm{O}_{2}$ (CAS[7722-84-1], 30 wt.\%, Sinopharm, Wuhan, China), glacial acetic acid HAc (CAS[64-19-7], 99.5\%, Sinopharm, Wuhan, China), sodium acetate NaAc 
(CAS[127-09-3], 99\%, Sinopharm, Wuhan, China), ammoniumdimolybdate ADM (CAS[27546-07-2], Mo 56.5\%, Macklin, Wuhan, China) and potassium iodide KI (CAS[7681-11-0], 99\%, Sinopharm, Wuhan, China) were used in kinetic studies. $\mathrm{H}_{2} \mathrm{O}_{2}$ decomposition experiments were performed in lucifugal bottles with different dosages of $\mathrm{CDots} / \mathrm{g}-\mathrm{C}_{3} \mathrm{~N}_{4}$ composite and under variable temperatures. The suspension was dispersed with ultrasonic sound for $1 \mathrm{~min}$ before the reaction. Afterwards, $\mathrm{H}_{2} \mathrm{O}_{2}$ was added to the suspension to trigger the reaction. Samples were extracted with a syringe and a filter ( $220 \mathrm{~nm}$, cellulose membrane) at fixed time intervals. The concentration of $\mathrm{H}_{2} \mathrm{O}_{2}$ as a function of time was determined by Ghormley triiodide method, where $\mathrm{I}^{-}$can be oxidized to $\mathrm{I}_{3}{ }^{-}$by $\mathrm{H}_{2} \mathrm{O}_{2}$ in faintly acid conditions catalyzed by ADM [62,63]. In detail, $0.2 \mathrm{~mL}$ sample was added to $1.6 \mathrm{~mL}$ water, followed by the addition of $0.1 \mathrm{~mL} 1 \mathrm{M} \mathrm{KI}$ and $0.1 \mathrm{~mL} 1 \mathrm{M} \mathrm{HAc} / \mathrm{NaAc}$ containing $0.03 \%$ ADM. The absorbance of produced $\mathrm{I}_{3}{ }^{-}$was measured at $350 \mathrm{~nm}$ by UV-vis spectrophotometer and the calibration curve of the absorbance of $\mathrm{I}_{3}{ }^{-}$as a function of $\mathrm{H}_{2} \mathrm{O}_{2}$ concentration was obtained with a linear correlation between absorbance and concentration in the range of $0.1-1 \mathrm{mM} \mathrm{H}_{2} \mathrm{O}_{2}$. The experimental error in the determination of $\mathrm{H}_{2} \mathrm{O}_{2}$ was less than $2 \%$.

Mechanistic studies: Tris(hydroxymethyl) aminomethane Tris (CAS[77-86-1], 99\%, Aldrich, Wuhan, China), acetoacetanilide AAA (CAS[102-01-2], 98\%, Macklin, Wuhan, China), ammonium acetate $\mathrm{NH}_{4} \mathrm{Ac}$ (CAS[631-61-8], 98\%, Sinopharm, Wuhan, China) and formaldehyde $\mathrm{CH}_{2} \mathrm{O}$ (CAS[50-00-0], Sinopharm, 37\% $\mathrm{wt} . \%$, Wuhan, China) were used in mechanistic studies. The experiments were carried out by using Tris as $\mathrm{HO}$ - scavenger (forming $\mathrm{CH}_{2} \mathrm{O}$ ) to quantify the produced $\mathrm{HO}$. indirectly. It is known that the amount of formed $\mathrm{CH}_{2} \mathrm{O}$ is quantitatively correlated with that of $\mathrm{HO}$. [17]. The decomposition experiments were carried out in $100 \mathrm{mM}$ Tris solution with fixed quantities of CDots $/ \mathrm{g}-\mathrm{C}_{3} \mathrm{~N}_{4}$ (SA/V $=4 \times 10^{5} \mathrm{~m}^{-1}$, SA and $V$ stands for the surface area of solid and the volume of solution) and $\mathrm{H}_{2} \mathrm{O}_{2}(5 \mathrm{mM})$. The $\mathrm{pH}$ values of solution were selected within the valid buffering range of Tris, namely $\mathrm{pH}$ 7.0-9.0 for investigating the effect of $\mathrm{pH}$. The produced $\mathrm{CH}_{2} \mathrm{O}$ was quantitatively determined by a modified Hantzsch method, where $\mathrm{CH}_{2} \mathrm{O}$ reacts with AAA in the presence of $\mathrm{NH}_{4} \mathrm{Ac}$ to form a dihydropyridine derivative with a maximum absorbance wavelength at $368 \mathrm{~nm}$ [19]. The calibration curve where the absorbance of produced dihydropyridine derivative was plotted as a function of $\mathrm{CH}_{2} \mathrm{O}$ concentration with linear correlation was obtained at $368 \mathrm{~nm}$ in the range of $0.04-1.3 \mathrm{mM} \mathrm{CH}_{2} \mathrm{O}$ for the conversion of absorbance to $\mathrm{CH}_{2} \mathrm{O}$ concentration. The experimental error in the determination of $\mathrm{CH}_{2} \mathrm{O}$ was less than $2 \%$.

\section{Conclusions}

In this work, a promising catalyst $\mathrm{CDots} / \mathrm{g}-\mathrm{C}_{3} \mathrm{~N}_{4}$ composite for degradation of non-biodegradable organic pollutants was synthesized via a two-step pathway including electrochemical exfoliation of graphite rod preparing CDots and thermal polymerization of CDots mixed urea. Through different characterization methods and kinetic experiments, it has been confirmed that CDots embed in $\mathrm{g}_{-} \mathrm{C}_{3} \mathrm{~N}_{4}$ matrix and such structure accounts for the synergetic catalytic performance of the composite. Kinetics of catalytic decomposition of $\mathrm{H}_{2} \mathrm{O}_{2}$ on CDots $/ \mathrm{g}-\mathrm{C}_{3} \mathrm{~N}_{4}$ composite were researched. The second-order rate constant $\left(\mathrm{k}_{2}\right)$ was measured to be $(1.42 \pm 0.07) \times 10^{-9} \mathrm{~m} \cdot \mathrm{s}^{-1}$ and the activation energy of the reaction was measured to be $(29.05 \pm 0.80) \mathrm{kJ} \cdot \mathrm{mol}^{-1}$ under the applied conditions. The effect of $\mathrm{pH}$ ( $\mathrm{pH}$ 7.0-9.0) on the production of HO- was also investigated by using Tris as a probe. It has been shown that the production of $\mathrm{HO}$. is strongly alkaline dependent and the maximum reaches at $\mathrm{pH} 8.0$ which is close to the $\mathrm{pKa}$ of Tris. A mechanism based on the adsorb-catalyze double reaction site theory has been proposed. This work implies that the photocatalyst (CDots $/ g-\mathrm{C}_{3} \mathrm{~N}_{4}$ composite) for water splitting or $\mathrm{H}_{2}$ evolution may also be applied as an alternative catalyst in degradation of non-biodegradable organic pollutants. The instinct kinetics and the mechanism can be referred to for further applications in related fields. 
Author Contributions: M.Y. conceived and designed the experiments; Z.L. and Q.S. performed the experiments; C.Z. and L.F. analyzed the data; T.X. contributed reagents/materials/analysis tools; M.Y. and Z.L. wrote the paper.

Funding: This work is supported by National Natural Science Foundation of China (21707108) and Independent Innovation Foundation of Wuhan University of Technology (20411057 and 20410962).

Conflicts of Interest: The authors declare no conflict of interest.

\section{References}

1. He, J.; Yang, X.F.; Men, B.; Wang, D.S. Interfacial mechanisms of heterogeneous Fenton reactions catalyzed by iron-based materials: A review. J. Environ. Sci. 2016, 39, 97-109. [CrossRef] [PubMed]

2. Nidheesh, P.V.; Gandhimathi, R.; Ramesh, S.T. Degradation of dyes from aqueous solution by Fenton processes: A review. Environ. Sci. Pollut. Res. 2013, 20, 2099-2132. [CrossRef] [PubMed]

3. Aval, A.E.; Hasani, A.H.; Omrani, G.A.; Karbassi, A. Removal of Landfill Leachate's Organic load by modified Electro-Fenton process. Int. J. Electrochem. Sci. 2017, 12, 9348-9363. [CrossRef]

4. Huang, J.; Shi, Q.; Feng, J.; Chen, M.; Li, W.; Li, L. Facile pyrolysis preparation of rosin-derived biochar for supporting silver nanoparticles with antibacterial activity. Compos. Sci. Technol. 2017, 145, 89-95. [CrossRef]

5. Freyria, F.S.; Armandi, M.; Compagnoni, M.; Ramis, G.; Rossetti, I.; Bonelli, B. Catalytic and Photocatalytic Processes for the Abatement of N-Containing Pollutants from Wastewater. Part 2: Organic Pollutants. J. Nanosci. Nanotechnol. 2017, 17, 3654-3672. [CrossRef]

6. Chen, C.Y.; Tang, C.; Wang, H.F.; Chen, C.M.; Zhang, X.Y.; Huang, X.; Zhang, Q. Oxygen Reduction Reaction on Graphene in an Electro-Fenton System: In Situ Generation of $\mathrm{H}_{2} \mathrm{O}_{2}$ for the Oxidation of Organic Compounds. Chemsuschem 2016, 9, 1194-1199. [CrossRef] [PubMed]

7. Santos, L.V.D.; Meireles, A.M.; Lange, L.C. Degradation of antibiotics norfloxacin by Fenton, UV and $\mathrm{UV} / \mathrm{H}_{2} \mathrm{O}_{2}$. J. Environ. Manag. 2015, 154, 8-12. [CrossRef] [PubMed]

8. Li, Y.G.; Hsieh, W.P.; Mahmudov, R.; Wei, X.M.; Huang, C.P. Combined ultrasound and Fenton (US-Fenton) process for the treatment of ammunition wastewater. J. Hazard. Mater. 2013, 244, 403-411. [CrossRef] [PubMed]

9. Nidheesh, P.V. Heterogeneous Fenton catalysts for the abatement of organic pollutants from aqueous solution: A review. RSC Adv. 2015, 5, 40552-40577. [CrossRef]

10. Oller, I.; Malato, S.; Sanchez-Perez, J.A. Combination of Advanced Oxidation Processes and biological treatments for wastewater decontamination-A review. Sci. Total Environ. 2011, 409, 4141-4166. [CrossRef] [PubMed]

11. Bokare, A.D.; Choi, W. Review of iron-free Fenton-like systems for activating $\mathrm{H}_{2} \mathrm{O}_{2}$ in advanced oxidation processes. J. Hazard. Mater. 2014, 275, 121-135. [CrossRef] [PubMed]

12. Li, P.; Xie, T.; Duan, X.; Yu, F.B.; Wang, X.; Tang, B. A New Highly Selective and Sensitive Assay for Fluorescence Imaging of $\mathrm{OH}$ in Living Cells: Effectively Avoiding the Interference of Peroxynitrite. Chem. Eur. J. 2010, 16, 1834-1840. [CrossRef] [PubMed]

13. Cao, Y.Q.; Sui, D.D.; Zhou, W.J.; Lu, C. Highly selective chemiluminescence detection of hydroxyl radical via increased pi-electron densities of rhodamine B on montmorillonite matrix. Sens. Actuators B Chem. 2016, 225, 600-606. [CrossRef]

14. Jing, Y.; Chaplin, B.P. Mechanistic Study of the Validity of Using Hydroxyl Radical Probes to Characterize Electrochemical Advanced Oxidation Processes. Environ. Sci. Technol. 2017, 51, 2355-2365. [CrossRef] [PubMed]

15. Yang, X.F.; Guo, X.Q. A novel fluorescence probe for the determination of hydroxyl radicals. Chem. J. Chin. Univ. 2001, 22, 396-398.

16. Fisher, S.C.; Schoonen, M.A.A.; Brownawell, B.J. Phenylalanine as a hydroxyl radical-specific probe in pyrite slurries. Geochem. Trans. 2012, 13, 1-18. [CrossRef] [PubMed]

17. Yang, M.; Jonsson, M. Evaluation of the $\mathrm{O}_{2}$ and $\mathrm{pH}$ Effects on Probes for Surface Bound Hydroxyl Radicals. J. Phys. Chem. C 2014, 118, 7971-7979. [CrossRef]

18. Lousada, C.M.; Jonsson, M. Kinetics, Mechanism, and Activation Energy of $\mathrm{H}_{2} \mathrm{O}_{2}$ Decomposition on the Surface of $\mathrm{ZrO}_{2}$. J. Phys. Chem. C 2010, 114, 11202-11208. [CrossRef]

19. Nash, T. The colorimetric estimation of formaldehyde by means of the Hantzsch reaction. Biochem. J. 1953, 55, 416-421. [CrossRef] [PubMed] 
20. Zheng, P.; Pan, Z.; Zhang, J. Synergistic Enhancement in Catalytic Performance of Superparamagnetic Fe3O4@Bacilus subtilis as Recyclable Fenton-Like Catalyst. Catalysts 2017, 7, 349. [CrossRef]

21. Yang, H.; Shi, B.; Wang, S. Fe Oxides Loaded on Carbon Cloth by Hydrothermal Process as an Effective and Reusable Heterogenous Fenton Catalyst. Catalysts 2018, 8, 207. [CrossRef]

22. Yang, M.; Zhang, X.; Grosjean, A.; Soroka, I.; Jonsson, M. Kinetics and Mechanism of the Reaction between $\mathrm{H}_{2} \mathrm{O}_{2}$ and Tungsten Powder in Water. J. Phys. Chem. C 2015, 119, 22560-22569. [CrossRef]

23. Hiroki, A.; LaVerne, J.A. Decomposition of Hydrogen Peroxide at Water-Ceramic Oxide Interfaces. J. Phys. Chem. B 2005, 109, 3364-3370. [CrossRef] [PubMed]

24. Domínguez, C.M.; Quintanilla, A.; Ocón, P.; Casas, J.A.; Rodriguez, J.J. The use of cyclic voltammetry to assess the activity of carbon materials for hydrogen peroxide decomposition. Carbon 2013, 60, 76-83. [CrossRef]

25. Lousada, C.M.; Trummer, M.; Jonsson, M. Reactivity of $\mathrm{H}_{2} \mathrm{O}_{2}$ towards different UO2-based materials: The relative impact of radiolysis products revisited. J. Nuclear Mater. 2013, 434, 434-439. [CrossRef]

26. Vilardi, G.; Di Palma, L.; Verdone, N. On the critical use of zero valent iron nanoparticles and Fenton processes for the treatment of tannery wastewater. J. Water Process Eng. 2018, 22, 109-122. [CrossRef]

27. Björkbacka, Å.; Yang, M.; Gasparrini, C.; Leygraf, C.; Jonsson, M. Kinetics and mechanisms of reactions between $\mathrm{H}_{2} \mathrm{O}_{2}$ and copper and copper oxides. Dalton Trans. 2015, 44, 16045-16051. [CrossRef] [PubMed]

28. Lousada, C.M.; LaVerne, J.A.; Jonsson, M. Enhanced hydrogen formation during the catalytic decomposition of $\mathrm{H}_{2} \mathrm{O}_{2}$ on metal oxide surfaces in the presence of $\mathrm{HO}$ radical scavengers. Phys. Chem. Chem. Phys. 2013, 15, 12674-12679. [CrossRef] [PubMed]

29. Pignatello, J.J.; Oliveros, E.; MacKay, A. Advanced oxidation processes for organic contaminant destruction based on the Fenton reaction and related chemistry. Crit. Rev. Environ. Sci. Technol. 2006, 36, 1-84. [CrossRef]

30. Diya'uddeen, B.H.; Aziz, A.R.A.; Daud, W.M.A.W. On the Limitation of Fenton Oxidation Operational Parameters: A Review. Int. J. Chem. React. Eng. 2012, 10, 1498-1502. [CrossRef]

31. Garcia-Segura, S.; Bellotindos, L.M.; Huang, Y.H.; Brillas, E.; Lu, M.C. Fluidized-bed Fenton process as alternative wastewater treatment technology-A review. J. Taiwan Inst. Chem. Eng. 2016, 67, 211-225. [CrossRef]

32. Pouran, S.R.; Raman, A.A.A.; Daud, W.M.A.W. Review on the application of modified iron oxides as heterogeneous catalysts in Fenton reactions. J. Clean. Prod. 2014, 64, 24-35. [CrossRef]

33. Yao, Y.J.; Chen, H.; Lian, C.; Wei, F.Y.; Zhang, D.W.; Wu, G.D.; Chen, B.J.; Wang, S.B. Fe, Co, Ni nanocrystals encapsulated in nitrogen-doped carbon nanotubes as Fenton-like catalysts for organic pollutant removal. J. Hazard. Mater. 2016, 314, 129-139. [CrossRef] [PubMed]

34. Zhou, F.Y.; Lu, C.; Yao, Y.Y.; Sun, L.J.; Gong, F.; Li, D.W.; Pei, K.M.; Lu, W.Y.; Chen, W.X. Activated carbon fibers as an effective metal-free catalyst for peracetic acid activation: Implications for the removal of organic pollutants. Chem. Eng. J. 2015, 281, 953-960. [CrossRef]

35. Zhu, Z.D.; Pan, H.H.; Murugananthan, M.; Gong, J.Y.; Zhang, Y.R. Visible light-driven photocatalytically active g- $\mathrm{C}_{3} \mathrm{~N}_{4}$ material for enhanced generation of $\mathrm{H}_{2} \mathrm{O}_{2}$. Appl. Catal. B Environ. 2018, 232, 19-25. [CrossRef]

36. Jiang, G.D.; Yang, X.X.; Wu, Y.; Li, Z.W.; Han, Y.H.; Shen, X.D. A study of spherical $\mathrm{TiO}_{2} / \mathrm{g}-\mathrm{C}_{3} \mathrm{~N}_{4}$ photocatalyst: Morphology, chemical composition and photocatalytic performance in visible light. Mol. Catal. 2017, 432, 232-241. [CrossRef]

37. Yan, J.; Fan, Y.M.; Lian, J.B.; Zhao, Y.; Xu, Y.G.; Gu, J.M.; Song, Y.H.; Xu, H.; Li, H.M. Kinetics and mechanism of enhanced photocatalytic activity employing $\mathrm{ZnS}$ nanospheres/graphene-like $\mathrm{C}_{3} \mathrm{~N}_{4}$. Mol. Catal. 2017, 438, 103-112. [CrossRef]

38. Bicalho, H.A.; Lopez, J.L.; Binatti, I.; Batista, P.F.R.; Ardisson, J.D.; Resende, R.R.; Lorencon, E. Facile synthesis of highly dispersed Fe(II)-doped $\mathrm{g}-\mathrm{C}_{3} \mathrm{~N}_{4}$ and its application in Fenton-like catalysis. Mol. Catal. 2017, 435, 156-165. [CrossRef]

39. Zhang, M.L.; Yao, Q.F.; Guan, W.J.; Lu, C.; Lin, J.M. Layered Double Hydroxide-Supported Carbon Dots as an Efficient Heterogeneous Fenton-Like Catalyst for Generation of Hydroxyl Radicals. J. Phys. Chem. C 2014, 118, 10441-10447. [CrossRef]

40. Wang, K.; Li, Q.; Liu, B.S.; Cheng, B.; Ho, W.K.; Yu, J.G. Sulfur-doped g- $\mathrm{C}_{3} \mathrm{~N}_{4}$ with enhanced photocatalytic $\mathrm{CO}_{2}$-reduction performance. Appl. Catal. B Environ. 2015, 176, 44-52. [CrossRef]

41. Zhao, D.M.; Chen, J.; Dong, C.L.; Zhou, W.; Huang, Y.C.; Mao, S.S.; Guo, L.J.; Shen, S.H. Interlayer interaction in ultrathin nanosheets of graphitic carbon nitride for efficient photocatalytic hydrogen evolution. J. Catal. 2017, 352, 491-497. [CrossRef] 
42. Zhou, M.; Yang, P.J.; Yuan, R.S.; Asiri, A.M.; Wakeel, M.; Wang, X.C. Modulating Crystallinity of Graphitic Carbon Nitride for Photocatalytic Oxidation of Alcohols. Chemsuschem 2017, 10, 4451-4456. [CrossRef] [PubMed]

43. Lin, K.Y.A.; Lin, J.T. Ferrocene-functionalized graphitic carbon nitride as an enhanced heterogeneous catalyst of Fenton reaction for degradation of Rhodamine B under visible light irradiation. Chemosphere 2017, 182, 54-64. [CrossRef] [PubMed]

44. Liu, J.; Liu, Y.; Liu, N.Y.; Han, Y.Z.; Zhang, X.; Huang, H.; Lifshitz, Y.; Lee, S.T.; Zhong, J.; Kang, Z.H. Metal-free efficient photocatalyst for stable visible water splitting via a two-electron pathway. Science 2015, 347, 970-974. [CrossRef] [PubMed]

45. Liu, Q.; Chen, T.; Guo, Y.; Zhang, Z.; Fang, X. Ultrathin g- $\mathrm{C}_{3} \mathrm{~N}_{4}$ nanosheets coupled with carbon nanodots as 2D/0D composites for efficient photocatalytic $\mathrm{H}_{2}$ evolution. Appl. Catal. B Environ. 2016, 193, $248-258$. [CrossRef]

46. Oh, J.; Lee, J.M.; Yoo, Y.; Kim, J.; Hwang, S.J.; Park, S. New insight of the photocatalytic behaviors of graphitic carbon nitrides for hydrogen evolution and their associations with grain size, porosity, and photophysical properties. Appl. Catal. B Environ. 2017, 218, 349-358. [CrossRef]

47. Liu, J.H.; Zhang, Y.W.; Lu, L.H.; Wu, G.; Chen, W. Self-regenerated solar-driven photocatalytic water-splitting by urea derived graphitic carbon nitride with platinum nanoparticles. Chem. Commun. 2012, 48, 8826-8828. [CrossRef] [PubMed]

48. Su, Y.H.; Chen, P.; Wang, F.L.; Zhang, Q.X.; Chen, T.S.; Wang, Y.F.; Yao, K.; Lv, W.Y.; Liu, G.G. Decoration of $\mathrm{TiO}_{2} / \mathrm{g}-\mathrm{C}_{3} \mathrm{~N}_{4}$ Z-scheme by carbon dots as a novel photocatalyst with improved visible-light photocatalytic performance for the degradation of enrofloxacin. RSC Adv. 2017, 7, 34096-34103. [CrossRef]

49. Fang, S.; Xia, Y.; Lv, K.L.; Li, Q.; Sun, J.; Li, M. Effect of carbon-dots modification on the structure and photocatalytic activity of $\mathrm{g}-\mathrm{C}_{3} \mathrm{~N}_{4}$. Appl. Catal. B Environ. 2016, 185, 225-232. [CrossRef]

50. Wang, X.F.; Cheng, J.J.; Yu, H.G.; Yu, J.G. A facile hydrothermal synthesis of carbon dots modified g- $\mathrm{C}_{3} \mathrm{~N}_{4}$ for enhanced photocatalytic $\mathrm{H}_{2}$-evolution performance. Dalton Trans. 2017, 46, 6417-6424. [CrossRef] [PubMed]

51. Wang, F.L.; Chen, P.; Feng, Y.P.; Xie, Z.J.; Liu, Y.; Su, Y.H.; Zhang, Q.X.; Wang, Y.F.; Yao, K.; Lv, W.Y.; et al. Facile synthesis of $\mathrm{N}$-doped carbon dots $/ \mathrm{g}-\mathrm{C}_{3} \mathrm{~N}_{4}$ photocatalyst with enhanced visible-light photocatalytic activity for the degradation of indomethacin. Appl. Catal. B Environ. 2017, 207, 103-113. [CrossRef]

52. Dadigala, R.; Bandi, R.; Gangapuram, B.R.; Guttena, V. Carbon dots and Ag nanoparticles decorated g- $\mathrm{C}_{3} \mathrm{~N}_{4}$ nanosheets for enhanced organic pollutants degradation under sunlight irradiation. J. Photochem. Photobiol. A 2017, 342, 42-52. [CrossRef]

53. Zhang, H.; Zhao, L.X.; Geng, F.L.; Guo, L.H.; Wan, B.; Yang, Y. Carbon dots decorated graphitic carbon nitride as an efficient metal-free photocatalyst for phenol degradation. Appl. Catal. B Environ. 2016, 180, 656-662. [CrossRef]

54. Lousada, C.M.; Yang, M.; Nilsson, K.; Jonsson, M. Catalytic decomposition of hydrogen peroxide on transition metal and lanthanide oxides. J. Mol. Catal. A-Chem. 2013, 379, 178-184. [CrossRef]

55. Yang, M.; Jonsson, M. Surface reactivity of hydroxyl radicals formed upon catalytic decomposition of $\mathrm{H}_{2} \mathrm{O}_{2}$ on $\mathrm{ZrO}_{2}$. J. Mol. Catal. A Chem. 2015, 400, 49-55. [CrossRef]

56. Fidalgo, A.B.; Dahlgren, B.; Brinck, T.; Jonsson, M. Surface Reactions of $\mathrm{H}_{2} \mathrm{O}_{2}, \mathrm{H}_{2}$, and $\mathrm{O}_{2}$ in Aqueous Systems Containing $\mathrm{ZrO}_{2}$. J. Phys. Chem. C 2016, 120, 1609-1614. [CrossRef]

57. Pirsaheb, M.; Moradi, S.; Shahlaei, M.; Farhadian, N. Application of carbon dots as efficient catalyst for the green oxidation of phenol: Kinetic study of the degradation and optimization using response surface methodology. J. Hazard. Mater. 2018, 353, 444-453. [CrossRef] [PubMed]

58. Lousada, C.M.; Johansson, A.J.; Brinck, T.; Jonsson, M. Mechanism of $\mathrm{H}_{2} \mathrm{O}_{2}$ Decomposition on Transition Metal Oxide Surfaces. J. Phys. Chem. C 2012, 116, 9533-9543. [CrossRef]

59. Ming, H.; Ma, Z.; Liu, Y.; Pan, K.; Yu, H.; Wang, F.; Kang, Z. Large scale electrochemical synthesis of high quality carbon nanodots and their photocatalytic property. Dalton Trans. 2012, 41, 9526-9531. [CrossRef] [PubMed]

60. Wei, Q.Y.; Yan, X.Q.; Kang, Z.; Zhang, Z.; Cao, S.Y.; Liu, Y.C.; Zhang, Y. Carbon Quantum Dots Decorated $\mathrm{C}_{3} \mathrm{~N}_{4} / \mathrm{TiO}_{2}$ Heterostructure Nanorod Arrays for Enhanced Photoelectrochemical Performance. J. Electrochem. Soc. 2017, 164, H515-H520. [CrossRef] 
61. Guo, F.; Shi, W.L.; Guan, W.S.; Huang, H.; Liu, Y. Carbon dots/g- $\mathrm{C}_{3} \mathrm{~N}_{4} / \mathrm{ZnO}$ nanocomposite as efficient visible-light driven photocatalyst for tetracycline total degradation. Sep. Purif. Technol. 2017, 173, 295-303. [CrossRef]

62. Hochanadel, C.J. Effects of Cobalt $\gamma$-Radiation on Water and Aqueous Solutions. J. Phys. Chem. 1952, 21, 587-594. [CrossRef]

63. Ghormley, J.A.; Stewart, A.C. Effects of $\gamma$-Radiation on Ice ${ }^{1}$. J. Am. Chem. Soc. 1956, 78, 2934-2939. [CrossRef] 